\title{
Cytokines in Systemic Lupus Erythematosus
}

\author{
Elaine V. Lourenço and Antonio La Cava* \\ Division of Rheumatology, Department of Medicine, University of California Los Angeles, Los \\ Angeles, CA 90095-1670, USA
}

\begin{abstract}
Systemic lupus erythematosus (SLE) is a chronic autoimmune disease characterized by the production of autoantibodies that can form immune complexes and deposit in tissues, causing inflammation and organ damage. There is evidence that interferons and some interleukins can have an active role in the pathogenesis of SLE and can contribute significantly to the immune imbalance in the disease, whereas the role of some cytokines (such as TNF) is still debated. This review discusses the activity of several cytokines in SLE, their effects on the immune cells in relation to the disease pathogenesis, and the promise and limitations of cytokine-based therapies in clinical trials for lupus patients.
\end{abstract}

\section{INTRODUCTION}

SLE is characterized by a dysregulation of the immune system that drives and perpetrates a condition of ineffective immune tolerance to nuclear components. The etiology and pathogenesis of SLE are not well understood, although it is accepted that both genetic susceptibility and environmental factors can contribute to the disease. For example, environmental factors such as the administration of certain drugs, the exposure to ultraviolet light and viral infection can promote the development and exacerbation of SLE-like disease, together with genetic factors that can contribute to disease susceptibility.

Cytokines are small soluble mediators released by many immune cell subsets and tissues. Cytokines have very important roles in modulating both the innate and adaptive immune responses. Both a defect and an excess of cytokine production, as well as abnormal responsiveness of immune cells to cytokines, can favor the development of immunemediated disease, suggesting the constant requirement of a fine balance among cytokines to maintain immune homeostasis.

Cytokines are typically grouped for their functional effects into T helper (Th)1, Th2, and Th17 cytokines (see below). In general, the overproduction of Th2 cytokines typically promotes B-cell hyperactivity and humoral responses, whereas $\mathrm{T}$ cell hyperactivity and inflammation frequently associate with an excess of Th1 and Th17 cytokines.

Considering that SLE is a multi-systemic autoimmune disease in which many immune cell subsets play a significant role in the disease pathogenesis, it is expected that cytokines belonging to more than one Th type may contribute to immune dysregulation and subsequent autoimmune abnormalities. Indeed, in SLE the contribution of cytokines from each group has been linked to the development and/or progression of the disease, both in mice and in humans. 


\section{CYTOKINES AND T HELPER (Th) CELL SUBSETS}

Cytokines are secreted by different immune cells such as lymphocytes, macrophages and dendritic cells (DC), and modulate the activation and/or functions of several target cells in both the innate and the adaptive immune systems. In the early phases of innate immune responses, antigen presenting cells (APC) such as DC and macrophages encounter and capture pathogens to present their antigens in the context of major histocompatibility complex (MHC) molecules to $\mathrm{CD}^{+}{ }^{+} \mathrm{T}$ cells, which recognize the MHC/peptide complex through the $\mathrm{T}$ cell receptor (TCR) and become fully activated upon engagement of costimulatory molecules (such as CD80 and CD86). The antigen recognition and binding of costimulatory molecules represent the first and second signals of activation, respectively. A third signal could be the secretion of cytokines, which are capable to bind to their specific receptors on the surface of the APC or the T cells to contribute to immune stimulation and/ or activation. The polarizing cytokine profile produced by the APC will determine in this context which type of activated effector $\mathrm{T}$ cells will be eventually involved in the immune response. Moreover, the Th cell ability to independently and synergistically help B-cell responses to antigens can bias the outcome of an immune response depending on the cytokine profile of the involved Th cells - Th type 1 and type 2 cells (Th1 and Th2 cells) [1, 2].

Antigen-specific and autoreactive Th cell clones can be divided into two groups on the basis of their patterns of lymphokines produced after antigen or lectin stimulation [1-3]. In addition to the Th1 and Th2 subsets, also $\mathrm{CD}^{+} \mathrm{T}$ cells, natural killer (NK) T cells, DC, and $\mathrm{B}$ cells can have dual patterns of cytokine secretion [4]. For example, in the mouse, B cells can be induced to differentiate into two types of effector B cells: Be1, which secrets IFN- $\gamma$, and Be2, which secrete IL-4 [5]. Because of their cytokine secretion, Be1 and Be2 subsets can modulate Th1 and Th2 development, respectively, when presenting antigen to naïve $\mathrm{T}$ cells [5]. CD8 T cells can also be divided in Tc1 and Tc2 cells depending on their Th1-like or Th2-like cytokine profile and, as mentioned before, a similar dichotomous polarity can be ascribed to both NKT cells and DC.

Finally, a third subset of Th cells that has recently been added to the former two groups is represented by the Th17 cells, whose main characteristic is to produce the pro-inflammatory cytokine IL-17.

\section{Th-TYPE CYTOKINES}

Th1 cells secrete interleukin (IL)-2, interferon (IFN)- $\gamma$ and tumor necrosis factor (TNF), and support cell-mediated functions such as macrophage activation, delayed-type hypersensitivity (DTH) responses, and immunoglobulin (Ig) isotype switching to $\mathrm{IgG} 2 \mathrm{a}$. On the other hand, Th2 cells secrete IL-4, IL-5, and IL-13, which lead to B-cell activation and can promote isotype switching to IgG1 and IgE [6] (Fig. 1).

Functionally, Th1 cells induce proinflammatory responses and contribute to the elimination of intracellular infections, whereas Th2 cells can mediate allergic reactions and anti-parasite responses [7].

Notably, both Th1 and Th2 cells have autocrine growth functions to sustain themselves and, importantly, they can reciprocally inhibit the opposite Th cell type $[8,9]$. In other words, the prototypical Th2 cytokine IL-4 can both promote Th2 clonal expansion while limiting the proliferation of Th1 cells and, conversely, the prototypical Th1 cytokine IFN- $\gamma$ can enhance Th1-cell growth and decrease at the meantime the Th2 responses [10]. Because of this property, it derives that the Th-cell lineage development can be determined by the types of cytokines that are present in the microenvironment, as IL-4 or IL-12 could respectively 
become essential for the induction of Th2 or Th1 cells from a common undifferentiated, uncommitted naïve precursor [11-13]. In particular, IL-12 would drive Th1 cell development through the activation in T cells of the signal transducer and activator of transcription (STAT) 4 and T-bet, which is a transcription factor that upregulates IFN- $\gamma$ and downregulates IL-4 and IL-5 expression [14]. In contrast, IL-4 would induce Th2 cell development through the activation of STAT6 [15-17], and Gata3 (a zinc-finger protein), leading to the upregulation of IL-4 and IL-5 and the downregulation of IFN- $\gamma$ expression (Fig. 1). Importantly, Gata3 and T-bet would also antagonize the development of the opposite subset of Th cells by directly regulating each other's expression [10,14]

Recently, the classical Th1/Th2 paradigm has been expanded to include the Th17-producing cells (Fig. 1), which are pro-inflammatory cells with a crucial role in certain autoimmune diseases [18]. Th17 cells are characterized by the expression of the transcription factor ROR $\gamma t$ and seem to reciprocally influence immunosuppressive regulatory T cells (Tregs) (see below), partly through the secretion of transforming growth factor (TGF)- $\beta$, IL- 6 and IL-17 [19-22]. This aspect is interesting because Tregs have an important role in maintaining peripheral tolerance and in preventing autoimmunity [23-25]. Tregs are numerically decreased in SLE patients and in NZB/ $\mathrm{W} \mathrm{F}_{1}$ lupus-prone mice [26-31]. Moreover, the depletion of Tregs in lupus mice results in increased titers of anti-nuclear antibodies (ANA) and accelerated development of glomerulonephritis [32], suggesting that the modulation of the number and/or function of the Tregs can be relevant in the pathogenesis of SLE.

To recapitulate, the differentiation towards Th1 or Th17 responses can positively influence the development and/or progression of autoimmune diseases (or transplant rejection), whereas Th2 typically exert protective effects in autoimmune diseases but have deleterious effects in other situations, such as e.g. in allergy [33].

\section{IMMUNE CELL SUBSETS IN SLE} Dendritic Cells

In general, cytokines at the priming site, antigen dose, affinity, costimulatory molecules, and the duration of exposure are factors that influence significantly the differentiation of $\mathrm{Th}$ subsets (Fig. 1), together with the type of APC (i.e. macrophages and DC favoring Th1, and B cells promoting Th2 differentiation) [34].

The DC are involved in the initiation of immunity, in the activation of naïve T cells, and in the stimulation of B cell growth and differentiation [35-38]. An abnormal function of the DC can promote dysregulated T and B cell functions, and in SLE the DC may play a crucial role in the disease pathogenesis through the production of IFN-a. In particular, sera from SLE patients can induce monocytes differentiation into DC, which capture antigens from dying cells to present them to T cells [39]. This IFN-a-dependent capacity of SLE sera to induce DC differentiation correlates with disease activity [39].

DC can also modulate Tregs functions, particularly in lupus-prone mice. DC can either inhibit Tregs through the production of IL-6 [40], or induce Tregs differentiation as plasmacytoid DC (pDC) through the production of TGF- $\beta$ and/or the inhibition of Th-17 cells $[41,42]$.

Overall, it appears that the pro-pathogenic or protective characteristics of the DC in SLE could relate to the type of $\mathrm{T}$ cell subsets that they can stimulate through the production of specific cytokine. 


\section{B Cells}

The hyperactivity of B cells in SLE has a crucial role in the production of antinuclear antibodies (ANA) [43].

Several lupus autoantigens that drive B cell response are located in apoptotic bodies and apoptotic blebs [44, 45], and SLE patients display increased apoptosis and defective clearance of such materials [46]. One possibility is that inappropriate production and/or clearance of apoptotic bodies and nucleosomes in SLE can render this immunogenic material accessible to the immune system for unusually long time, thus contributing to the development of autoimmunity [47].

In this context, it is worth mentioning that BLyS - a member of the TNF family of cytokines - can represent an essential survival factor for B cells, and BLyS signaling causes upregulated expression of the anti-apoptotic molecule bcl-2. Not only BLyS is elevated in some SLE patients [48, 49], but constitutive BLyS overexpression in mice leads to an autoimmune phenotype similar to lupus nephritis, whereas the deletion of BLyS results in a block of B cell development in which mature B cells are absent [50]. Notably, BLyS antagonists reduce disease severity and delay disease progression in autoimmune animals, making BLyS an attractive target for antagonism in SLE. Because of that, several approaches are under way to antagonize BLyS, including a fully human antibody and soluble BLyS receptors that is currently tested in clinical trials [51].

T Cells

Studies in SLE patients and murine models have confirmed the importance of cytokines produced both by Th1 and Th2 subsets in the pathogenesis of the disease.

Early reports suggested that SLE was a Th2 or a mixed Th1 and Th2 driven disease [52] . There were several indications to support such assumption. For example, patients with lupus nephritis (LN) had significantly lower levels of serum IL-12 and IFN- $\gamma$ than IL-4 and IL-10, suggesting that a shift towards the type 2 cytokine phenotype could have been associated with LN [53]. SLE patients also had increased production and serum levels of the type 2 cytokine IL-10, whose levels correlated with titers of anti-dsDNA antibodies, although not with the disease activity [54]. Additionally, a Th2 polarization in SLE was observed during pregnancy, in which elevated levels of IL-10 were found in the placenta, amniotic fluid and serum [55]. Finally, increased humoral immune responses could account for disease flares (characterized by cutaneous, articular, kidney and/or central nervous system manifestations) during pregnancy [56].

However, an abnormal expression of Th1 cytokines is also evident in SLE patients, and the levels of IFN- $\gamma$, TNF- $\alpha$, and IL-12 are typically higher than in healthy matched controls [57].

In $\mathrm{NZB} / \mathrm{W} \mathrm{F}_{1}$ lupus mice, the cytokine profile of $\mathrm{CD}^{+} \mathrm{T}$ cells is shifted towards a Th1 phenotype, and the frequency of Th cells expressing IFN- $\gamma$ correlates with age, anti-dsDNA immunoglobulin $\mathrm{G}(\mathrm{IgG})$ titers, and proteinuria. The IFN- $\gamma / \mathrm{IL}-4$ ratio also indicates a shift towards Th1-type responses during disease development [58]. Furthermore, the treatment of NZB/W $F_{1}$ with anti IFN- $\gamma$ or anti IFN- $\gamma$ receptor antibodies abrogates the humoral and end-organ autoimmunity $[59,60]$. However, autoantibody production and end-organ disease are diminished by the treatment with anti-IL-10 antibodies, suggesting an important role of Th2 cytokines as well [61].

Overall, it appears that both Th1 and Th2 cytokines are important in the pathogenesis of murine lupus. Both IFN- $\gamma^{-/-}$and IL- $4^{-/-}$lupus-prone mice MRL/lpr have reduced 
lymphadenopathy and end-organ disease when compared to cytokine-sufficient mice [62]. Therefore, murine lupus-like disease can associates with IFN- $\gamma$ and IL-12, but also with IL-4 and IL-10 [63-65].

In a mouse lupus model, the treatment with IL-4 antagonists reduces anti-DNA titers and renal disease [66], whereas treatment with antibodies to IFN- $\gamma$ does not ameliorate disease, indicating a requirement for Th2 cytokines [67].

In another lupus model, the NZM.2410 mouse, a genetic deficiency of STAT6 (a transcription factor with pivotal role in the development of Th2 cytokines) [15-17] and/or the treatment with anti-IL-4 antibodies ameliorate glomerulosclerosis and kidney disease, whereas a genetic deficiency of STAT4 (a transcription factor involved in the development of Th1 cytokines) accelerated lupus nephritis [68], suggesting a correlation between increased IL-4 levels and development of lupus nephritis in these mice [69]. Notably, a single-nucleotide polymorphisms (SNP) haplotype in the third intron of STAT4 in humans is associated with increased risk for SLE (and rheumatoid arthritis) [70].

\section{SLE and Toll-Like Receptors (TLRs)}

In SLE, a central event in the pathogenesis of the disease is the formation of autoantibodies forming immunocomplexes (ICs) that can cause inflammation by depositing in and damaging host tissues. Murine models of SLE have suggested that multiple genetic defects can cause a loss of self tolerance and drive the formation of autoantibodies, but cytokines and chemokines produced in the course of the disease also have a very important role, so that the two aspects may be linked pathogentically. Moreover, an important feature in the pathogenesis of lupus is the activation of the Toll-like receptors (TLRs). During infection, pathogen-associated molecular patterns (PAMPs) may bind to TLR and induce the production of innate cytokines that can stimulate the host defense. The PAMPs of invading pathogens - which can be lipids, proteins, and nucleic acids - are detected by innate immune cells through their binding to TLRs and trigger adaptive immune responses [71], leading to the activation of type I IFN genes and the production of inflammatory cytokines [72]. However, in certain circumstances such as in a genetically predisposed host, these events could also promote autoimmune responses.

Multiple TLRs could be involved in the pathogenesis of SLE, as suggested by studies in MRL/lpr mice deficient in MyD88 (an adaptor for the signal transduction for all TLRs except TLR-3) [73]. MyD88 gene deficiency delays the mortality and prevents nephritis and immunologic aberrations in MRL/lpr mice, and MyD88-knockout MRL/lpr mice produce less anti-dsDNA Ig, IFN-a, IL-12, IL-6, and IFN- $\gamma$ than wild-type mice. These mice develop a severe systemic autoimmunity when treated with polyinosinic-cytidylic acid (pIC), a TLR-3 ligand [74, 75]. Moreover, endogenous or exogenous CpG motifs (a ligand for TLR-9) can induce activate DC to produce IL-6, which is an inhibitory cytokine for the Treg-mediated suppression of autoreactive T cells [76]. Also, activation of TLRs can induce autoantibody production [77], and MRL/lpr mice treated with CpG-DNA or imiquimod (a TLR-7 ligand) develop more severe lupus nephritis than controls [78, 79].

Also, antibodies that bind DNA forming ICs are promoted by TLR-9-dependent mechanisms [80], and autoantibodies to certain RNA-associated autoantigen may initiate SLE by stimulating TLR-7 and/or TLR-8 [81, 82]. Moreover, interaction of TLR-3 by viral double-stranded RNA (dsRNA) activates DC to secrete type I IFN and cytokines associated with disease activity in SLE [83]. 
Taken together, these data suggest that a genetic predisposition combined with the stimulation of innate immune responses through the activation by TLRs could induce the modulation of key cytokines promoting loss of tolerance in susceptible individuals.

\section{CYTOKINES IN SLE}

\section{Interferons and SLE}

Interferons (IFNs) have multiple effects on immunity. Although initially identified on the basis of their anti-viral properties, IFNs affect several immune functions including cell differentiation, proliferation and survival of $\mathrm{B}, \mathrm{T}$, and NK cells, macrophages, DC, in addition to the modulated production of other cytokines. IFNs are produced by distinct cell types and are classified as either type I or type II IFNs.

IFNs could influence SLE pathogenesis both directly (acting on selected immune cell subsets), or indirectly. For example, one lupus susceptibility gene in lupusprone NZB/W $\mathrm{F}_{1}$ and NZB mice is Ifi202, whose encoded protein is produced by two IFN-inducible genes, Ifi202a and Ifi202b [84]. Ifi202 can be induced rapidly in response to lipopolysaccharide (LPS) in mature bone marrow-derived DC (BMDC) of NZB and NZB/W $\mathrm{F}_{1}$, but not in BMDC of NZW mice [85], and could exert its pathogenic actions by binding transcription factors with subsequent inhibition of cell proliferation and apoptosis [86] and/or by positively regulating the expression of IL-12 in DC [85].

\section{Type 1 IFN: IFN- $\alpha$}

The type I IFNs family includes at least 13 IFN- $\alpha$ subtypes, as well as IFN- $\beta$, IFN- $\omega$, IFN- $\kappa$ and IFN- $\varepsilon$. Among these members, IFN- $a$ is the most studied. This cytokine can act on both innate and adaptive immune responses. IFN- $\boldsymbol{\alpha}$ is among the first cytokines produced in the course of innate response and represents a first line of host defense. The most actively type-I IFN (mostly IFN-a)-producing cells are the plasmacytoid DC (pDC), initially designed as natural IFN-a producing cells $[87,88]$.

The finding that SLE-derived ICs containing nucleic acid from dying cells can induce IFN-a in $\mathrm{pDC}$ suggests a key role for $\mathrm{pDC}$ and their IFN-a production in the pathogenesis of SLE [89]. IFN-a could promote DC maturation following uptake of self-material [90, 91], and ICs could act as endogenous IFN- $a$ inducers. Then, IFN- $a$ would promote monocyte differentiation into DC.

But how is IFN-a produced in SLE? Since pDC express TLR1, 6, 7, 9 and 10, these receptors might be involved in the process $[92,93]$. Both exogenous and endogenous stimuli containing DNA or RNA could be potential TLRs ligands. The production of type I IFN by pDC through TLR binding would induce maturation of myeloid DC (mDC), increase Th1 cytokine production (particularly IFN- $\gamma$ ), promote Ig class switching in B cells, and increase IL-10 and Blys/BAFF in monocytes [72].

Studies using type I IFN receptor knockout mice have shown beneficial effects on the spontaneous course of lupus [94, 95], and mice lacking IFN- $\mathbf{a} / \mathrm{BR}$, the common receptor for type-I IFN, display significantly reduced autoimmunity, kidney disease and mortality [95]. Conversely, continuous in vivo expression of IFN-a dramatically accelerates the development of manifestations of lupus in young lupus-prone mice [96]. However, MRL/lpr mice that lack the type I IFN receptor have accelerated lymphoproliferation, autoantibody production and end organ disease, suggesting a protective role of type I IFN in this lupus model [97]. 
In humans, a contribution of IFNs to the pathology of SLE has been recognized as early as in 1979. Initial studies in SLE patients described elevated serum levels of IFN-a that correlated with both disease activity and severity [98-100]. Also, IFN-a levels were also correlated with anti-double-stranded DNA (dsDNA) antibodies, complement activation, and circulating IL-10 [101].

A role for IFN- $a$ in the initiation of SLE also comes from the observation that therapeutic administration of this cytokine to patients with viral infection or tumors can induce autoantibodies and, occasionally, lupus [102, 103]. This observation raises the question of whether type I IFNs on an appropriate genetic background could trigger SLE. In this regard, the characterization of serum IFN- $a$ activity in affected and unaffected individuals from two large SLE family registries showed a tendency to high serum IFN-a activity in SLE patients as well as in their healthy first-degree relatives, as compared to healthy controls. High IFNa activity was detected in $18 \%$ of healthy first-degree relatives and $47 \%$ of SLE patients, suggesting that high serum IFN-a activity could be a heritable risk factor in SLE [104].

Importantly, microarray screen on target tissues and leukocytes of approximately 2/3 of SLE patients show an "IFN signature" of upregulated IFN-responsive genes that correlates with disease activity and the involvement of kidney or central nervous system [105]. Moreover, genetic abnormalities resulting in increased IFN-I production and/or signaling associate with SLE [106].

The predominant stimulus for IFN-inducible gene expression in SLE seems IFN- $a$, considering that peripheral blood mononuclear cells of many SLE patients display a coordinate activation of IFN-a- (but not IFN- $\gamma$ ) induced genes [107].

\section{Type II IFN: IFN-Y}

IFN- $\gamma$ is a pleiotropic cytokine with a broad spectrum of actions. This cytokine is the only type II IFN and is produced early in the immune response by NK cells. Once the adaptive immune response is initiated, this IFN is produced by activated T cells. IFN- $\gamma$ has been extensively studied in both normal and pathological immune responses, and in the induction of other proinflammatory cytokines such as TNF. IFN- $\gamma$ has also been studied in the induction of apoptosis in renal parenchymal cells, as IFN- $\gamma$ can promote tissue injury when produced in excess [108].

The pathogenetic role of IFN- $\gamma$ has been demonstrated in both human and murine lupus [109]. SLE patients have elevated levels of IFN- $\gamma$ that associate with disease activity [110].

Studies in NZB/W $\mathrm{F}_{1}$ mice show accelerated disease in animals receiving IFN- $\gamma$ or its inducers, and delayed disease in mice receiving anti-IFN- $\gamma$ antibody [59]. Other studies in lupus-prone mice indicate that the absence of IFN- $\gamma$ leads to increased survival and reduced glomerulonephritis $[60,111,112]$, and MRL/lpr or NZB/W $F_{1}$ mice in which the IFN- $\gamma$ or IFN- $\gamma \mathrm{R}$ gene had been deleted show significant reduction of histologic and serologic disease, and prolonged survival $[111,113]$.

High levels of IFN- $\gamma$ are found in lymphoid organs and in disease-affected tissues of lupus mice, particularly at the late stages of the disease, with the most abundant levels observed in $\mathrm{MRL} / \mathrm{lpr}$ lupus mice in correlation with disease severity $[63,114]$. Also, mice with a normal background that transgenically overexpress IFN- $\gamma$ in the epidermis develop inflammatory skin disease as well as a lupus-like syndrome with ANA and ICs deposits in the kidney [115]. 
From a molecular standpoint, the biological effects of IFNs are mediated through the Jak/ STAT pathway, where both IFN- $\alpha / \beta$ and IFN- $\gamma$ activate the transcription factor STAT1. Of note, the expression and activation of STAT1 are significantly increased in lupus nephritis in MRL/lpr mice [116], and SLE patients with diffuse proliferative lupus nephritis have activated STAT-1 in their diseased kidneys [117].

\section{IL-2}

The Th1 cytokine IL-2 is the major autocrine and paracrine growth factor for T cells, and the quantity of IL-2 synthesized is an important determinant of the magnitude of T celldependent immune responses. It is also a growth factor for NK and B cells, in which for the latter cells it acts as a stimulus for antibody synthesis. IL- 2 is synthesized and secreted by activated $\mathrm{CD} 4^{+} \mathrm{T}$ cells, and in lesser quantities by $\mathrm{CD} 8^{+} \mathrm{T}$ cells.

IL-2 plays a central role during the initial phase of an immune response by promoting cell cycle progression in lymphocytes. Furthermore, it activates T cells apoptosis, which is an important mechanism to terminate $\mathrm{T}$ cell immune responses and to maintain self-tolerance $[118,119]$. Due to its role in immunoregulation, deficient IL-2 production associates with increased rate of infection as well as reduced apoptosis [120]. Recent reports have also indicated that IL-2 can promote generation of Tregs and inhibition of Th17 cells [121], a role consistent with the loss of tolerance and generalized autoimmunity in mice genetically deficient of IL-2 or IL-2 receptor $a$ or $\beta$ [122].

Functionally, murine and human T lymphocytes in SLE exhibit both deficient proliferation and defective IL-2 production [123-125]. Studies on the transcriptional pathway of IL-2 have shown that the repression of this gene can be responsible for the decreased production of IL-2 by SLE T cells [126]. Other studies indicated that IgG from SLE patient sera could inhibit IL-2 production [127], and that SLE serum IgG could activate $\mathrm{Ca}^{2+} /$ calmodulindependent kinase IV (CaMKIV) - which is increased in the nucleus of SLE T cells - and CaMKIV inhibited the IL-2 promoter and thus IL-2 expression [128]. Another explanation to the responsiveness of SLE T cells to IL-2 is the decreased number of the high affinity IL-2R on these cells - demonstrated in patients with active and inactive SLE [129].

Regarding to the soluble form of the IL-2R (sIL-2R), different studies have demonstrated elevated serum sIL-2R levels in patients with SLE compared with healthy controls, and the levels were significantly higher during active SLE and associated with lymphopenia, renal disorders, decreased C3 level, increased anti-DNA [130, 131], and low sIL-2R urinary levels (suggesting a deficient clearance of sIL-2R that could possibly contribute to the accumulation of these soluble receptors in the patients' serum) [131].

IL-12 is a proinflammatory cytokine made of two subunits (IL-12p35 and IL-12p40). This cytokine has a key role in the induction of Th1 cells differentiation and links innate and adaptive immunity [132]. It induces IFN- $\gamma$ production by $\mathrm{T}$ cells and thereby resistance to intracellular infection [133].

Many experimental and clinical studies have implicated IL-12 in the pathogenesis of autoimmune inflammation, including lupus. It has been reported that serum concentration of IL-12 was higher in SLE patients compared to healthy controls [134]. In contrast, it was reported a decreased expression of p35 or absence of IL-12p70 in SLE patients [135, 136]. Levels of serum IL-12 or production of IL-12 by peripheral blood mononuclear cells (PBMCs) from patients with LN were significantly lower than those without LN [53]. In lupus mice, the expression of IL-12 was increased in DC, in kidney-infiltrating mononuclear cells and tubular epithelial cells, and young MRL/lpr mice had accelerated 
glomerulonephritis when injected with IL-12 [65, 137]. Moreover, IL-12-secreting MRL/lpr tubular epithelial cells implanted under the kidney capsule before renal disease promoted IFN- $\boldsymbol{\gamma}$-dependent nephritis [138]. The same study demonstrated that IL-12 recruits CD4, $\mathrm{CD} 8$, and double negative $\left(\mathrm{CD}^{-}{ }^{-} \mathrm{CD} 8^{-}\right) \mathrm{T}$ cells into the kidney, activates kidney-infiltrating $\mathrm{T}$ cells to produce IFN- $\gamma$, and promotes the expansion of CD4 T cells in the kidney.

In another report, MRL/lpr with a genetic deficiency in IL-12 had reduced kidney, lacrimal gland, and salivary gland pathology; diminished lymphadenopathy; and prolonged survival [139]. The decreased severity of renal disease was associated with fewer IFN- $\gamma$-expressing cells intrarenally in the IL-12 ${ }^{-/}$kidneys compared with controls. However, while the protection from lung, skin, and lacrimal and salivary gland pathology was enduring, renal pathology continued to progress, suggesting that IL-12 is instrumental in the initiation phase of the disease, but other nephritogenic molecules contribute to renal disease [139].

\section{IL-18}

IL-18 is a member of the IL- 1 cytokine family that can stimulate IFN- $\gamma$ production in CD8 and NK cells in mice and in humans [140]. It can act, synergistically with IL-12 or independently, to promote Th1 cell development [141], and is one plausible candidate along with IL-12 in driving LN in MRL/lpr mice [140]. Like IL-12, IL-18 is upregulated in the kidney and serum of MRL/lpr mice with $\mathrm{LN}$, and further increases with advanced disease $[137,138]$. The production of IL-18 in MRL/lpr is not confined to monocytes infiltrating the kidney but it is detected primarily in tubular epithelial cells (TECs). Furthermore, activated TECs induce IFN- $\gamma$ production in MRL/lpr T cells through IL-18 [142]. Even in IL-12-/MRL/lpr mice, the levels of intrarenal IL-18 are elevated [139], and MRL/lpr mice injected daily with IL-18 or IL-18 plus IL-12 have accelerated proteinuria, glomerulonephritis, vasculitis, and elevated levels of proinflammatory cytokines [143]. In lupus patients, expression of IL-18 is higher in renal biopsies and in serum/plasma of nephritic patients than in those without renal disease [144, 145]. Also, increased levels of IL-18 in SLE sera strongly correlate with active disease (SLEDAI > 8) [146].

Overall, these data indicate the importance of IL-12 and IL-18 in the pathogenesis of SLE and the possibility of targeting these cytokines for therapeutic intervention in the disease, in addition to suggesting their possible use as biomarkers in lupus renal disease.

\section{IL-23}

IL-23 and IL-27 are structurally related to IL-12 and can induce the production of IFN- $\gamma$ by $\mathrm{CD}^{+} \mathrm{T}$ cells, similarly to IL-12 [147]. IL-23 has a subunit, p19, which combines with the subunit p 40 of IL-12 to form the biologically active cytokine IL-23. Secreted by APC, IL-23 binds to IL-12R $\beta 1$, but not IL-12R $\beta 2$, and activates the transcription factor STAT4 [148]. The IL-23 receptor, IL-23R, is present on NK cells, DC, monocytes, macrophages, activated and/or memory $\mathrm{T}$ cells [41].

IL-23 is essential to promote the expansion and survival of Th17 cells [149]. Despite the structural similarity with IL-12, IL-23 is not involved in the differentiation of naïve T cells into Th1 cells $[148,150]$.

There is evidence that IL-23 is important during an early immune response against pathogens through the induction of IL-17 by $\gamma \delta$ and $\alpha \beta$ T cells and NK cells. For example, IL-23 is produced by DC and macrophages after exposure to microbial products [151], and mice lacking bioactive IL-12, but expressing the IL-12 p40 subunit, develop protective immunity against Mycobacterium bovis, Mycobacterium tuberculosis and Salmonella enteritidis [152, 153]. 
IL-23 secretion can also result in the induction of proinflammatory cytokines, such as IL-1, IL-6, IL-8 and TNF that recruit neutrophils at the site of infection in the beginning of the immune response, and Th17 cells in the late phase of the response [151].

Although IL-23 secretion in the early stage of an infection has important role in mounting a local protective response, it might also contribute to autoimmune pathologies [151]. Mice

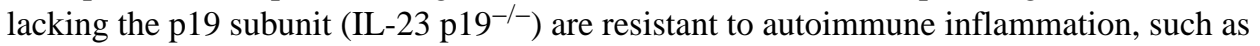
experimental autoimmune encephalomyelitis and collagen-induced arthritis [150, 154], but they present normal immune responses to microbial infections such as Toxoplasma gondii, in which IL-12 has an important role [155].

Evidence for a role of IL-23/Th17 pathway in psoriasis, rheumatoid arthritis, multiple sclerosis and inflammatory bowel disease is coming out [156], whereas the role of IL-23 in SLE is still speculative. Recently reported, the expression of p40 and p19 subunits was increased in untreated SLE patients, and decreased in SLE patients treated with immunosuppressors [157]. Also, the expression of p40 and p19 was higher in active SLE patients (SLEDAI >10) than in inactive patients [157].

\section{IL-10}

IL-10 is an anti-inflammatory cytokine that was first isolated from mouse Th2 cells and was named cytokine synthesis inhibitory factor (CSIF) because of its inhibitory activity on Th1 cells [158]. It is now known that also B cells, mast cells, eosinophils, macrophages, DC, $\mathrm{CD} 8^{+} \mathrm{T}$ cells, and regulatory CD4 ${ }^{+} \mathrm{T}$ cells can produce IL-10 [159].

IL-10 is a multifunctional cytokine with properties that involve an inhibitory activity on T cells, monocytes, macrophages, DC, NK cells, the inhibition of class II MHC and costimulatory molecules with subsequent inhibition of proinflammatory cytokine and chemokines secretion [160].

Because of the anti-inflammatory effects of IL-10, IL-10-deficient mice develop exaggerated inflammatory bowel disease [161, 162], whereas the neutralization of IL-10 favors the resolution of infection by intracellular pathogens [161, 163]. In addition to its inhibitory effects, IL-10 also plays a stimulatory role in the growth and/or differentiation of $\mathrm{B}$ cells, enhancing Ig production. Moreover, IL-10 is a growth factor for mouse mast cells and thymocytes, it induces recruitment, proliferation and cytotoxic activity of CD8 T cells in mice and humans, and is important in the function of subsets of regulatory T cells [164].

Overall, IL-10 influences infectious diseases, acute and chronic inflammatory diseases, cancer, transplantation, and autoimmunity [165].

In SLE, IL-10 promotes B cell proliferation and Ig class switching, resulting in increased production of antibodies [166]. A correlation of IL-10 and SLE was described for the first time in 1993, when it was observed the production of IL-10 by monocytes and B lymphocytes isolated from PBMCs of lupus patients [167]. Following studies showed that the production of IL-10 by SLE PBMCs is derived from monocytes and B cells, but the correlation of IL-10 and disease severity was infrequently observed [165, 168]. Other reports found instead a correlation between the increased concentration of IL-10 in the serum of lupus patients and disease activity and anti-dsDNA levels [169-171], or increased apoptosis in T cells [172].

In lupus mice, antibodies anti-IL-10 can delay autoimmunity. The treatment increased mice survival and correlated with decreased anti-dsDNA antibodies, reduced proteinuria, and decreased incidence and severity of kidney glomerular lesions [173]. 
TNF- $a$ is an important mediator of host responses to infectious organisms. The major cellular source of TNF- $a$ are the activated mononuclear phagocytes, although activated T cells, NK cells and mast cells can also secrete this cytokine. Initially synthesized as a transmembrane protein, TNF- $a$ is cleaved off the membrane to produce a soluble form, which acts as a mediator of both natural and acquired immunity, linking immune responses with acute inflammation. TNF-a has differential effects on B cells, T cells and DC, as well as pro-apoptotic effects [174].

TNF- $a$ is critical in containing infections, but it can be harmful or lethal when produced in great quantities, and it is implicated in the pathogenesis of several autoimmune diseases such as rheumatoid arthritis, Crohn's disease, and multiple sclerosis [174]. In patients treated with TNF inhibitors for diseases other than SLE, the use of anti-TNF agents for long periods could associate with adverse events including the development of autoimmune diseases [175].

Since TNF-a regulates the production of IFN-a by pDC [91], neutralization of TNF in patients undergoing anti-TNF therapy could possibly sustain the production of IFN- $a$ by pDC [176] and, without the negative regulation of IFN-a secretion, the overproduction of this cytokine could promote autoimmunity. Support for this hypothesis comes from reports of over-expression of IFN-a-regulated genes in leukocytes of patients with systemic juvenile arthritis treated with TNF antagonists [176], and from the fact that patients with active SLE display an IFN-a signature in their blood [177].

The effects of TNF- $a$ in SLE likely derive from its proinflammatory properties and effects on B cells, T cells, and pDC. Yet, the role of TNF-a in SLE is not clear, considering that some reports describe protective effects and other reports indicate harmful effects on the disease. The levels of TNF- $a$ are high in the serum and kidneys of lupus patients with active or inactive disease when compared to healthy controls [178]. In lupus mice, TNF- $a$ is increased in sera and kidneys, and the treatment with TNF- $a$ induces lethal renal injury $[179,180]$. Also, the administration of low dose of TNF- $a$ to NZB/W F $F_{1}$ mice from 4-8 months of age accelerates renal disease and mortality, while this effect is not observed with higher doses [180].

At a molecular level, the mRNA expression of TNF adapter proteins including TNF receptor-associated death domain (TRADD) protein, Fas-associated death domain (FADD) protein, receptor-interacting protein 1 (RIP-1), and TNF receptor-associated factor-2 (TRAF-2) are significantly reduced in SLE PBMCs, and negatively correlate with SLE activity index, possibly as a secondary defect in apoptosis [181].

In regard to the beneficial effects in SLE, TNF-a could enhance the clearance of circulating ICs [182] and reduce the severity of IC-induced murine LN [183].

\section{IL-17 and TGF- $\beta$}

Th17 cells got their name from their production of IL-17A and IL-17F, although Th17 also produce other cytokines such as TNF and IL-6, in addition to chemokines [156] (Fig. 1).

The role of Th17 cells in immunity is still under investigation, although it has been shown that production of IL-17 and other immune modulators by these cells help the clearance of pathogens such as extracellular bacteria $[184,185]$. However, a role of Th17 cells in autoimmunity has been described [149, 186], and dysregulated activation of Th17 cells and continuous production of IL-17 has been observed in experimental autoimmune 
encephalomyelitis, collagen-induced arthritis inflammatory bowel disease [147] and, more recently, in a model of lupus-like disease [42].

IL-17 (commonly known as IL-17A) is a proinflammatory cytokine with multiple functions in the regulation of tissue inflammation. So far, six different IL-17 have been described. They constitute the IL-17 cytokine family, whose members are denoted IL-17A through F and are structurally homologous to each other. The receptors for the IL-17 family (five have been described so far) are distributed ubiquitously in cells and tissues in both humans and mice and are called IL-17R (the dominant receptor for IL-17A), IL-17RB, IL-17RC, IL-17RD, and IL-17RE. The engagement of the IL-17R activates both the transcription factor NF- $\kappa \beta$ and the Jnk kinase pathways [187].

The main producers of IL-17 are the memory $\mathrm{CD}^{+} \mathrm{T}$ cells named Th17 cells, but other cells such as $\gamma \delta \mathrm{T}$ cells, $\mathrm{CD}^{+}$memory T cells, eosinophils, neutrophils and monocytes can also produce it. IL-17 has a key role in tissue neutrophil recruitment through the induction of granulocyte macrophage colony-stimulating factor, CXC ligand 1, TNF and IL-8 [151, 188]. The neutrophil recruitment is important in controlling acute infection, and IL-17R-deficient mice are very sensitive to lethal bacterial infection and display a reduction in granulocyte colony-stimulating factor and macrophage inflammatory protein 2 in the lung [189].

Also, IL-17-deficient mice have reduced contact hypersensitivity, delayed-type hypersensitivity and airway hypersensitivity response [190].

The Th17 lineage differentiation depends on TGF- $\beta$ and IL- 6 , and is influenced by IL-1 $\beta$ and TNFa, among other cytokines [20-22, 186], in addition to the costimulation through CD28 and inducible costimulator (ICOS) [191]. The expansion of Th17 cells and the production of IL-17 are then promoted by IL-23 secreted by the APC (although this cytokine does not represent a differentiation factor for Th17 cells) [20, 151].

Both IFN- $\gamma$ and IL-4 are inhibitory for Th17 cells [186] and, notably, Th17 may oppose the activity of Tregs, the subset of $\mathrm{CD}^{+}{ }^{+} \mathrm{T}$ cells characterized by the expression of the IL-2R $\mathrm{a}$ chain (CD25) and the transcription factor Foxp3 that suppress autoreactive immune responses [20, 192-194]. Tregs develops intrathymically and extrathymically. The first, known as naturally occurring Tregs, constitute $5-10 \%$ of $\mathrm{CD}^{+}$cells in mice and about $1-2 \%$ in humans and do not require TGF- $\beta$ for their generation. The extrathymic, peripherally induced Tregs, known as adaptive Tregs, are induced in the periphery [195]. The conversion of naïve peripheral effector $\mathrm{CD} 4^{+} \mathrm{CD} 25^{-}$cells to $\mathrm{CD} 4^{+} \mathrm{CD} 25^{+}$Foxp $3^{+} \mathrm{T}$ cells is a process that depends on TCR signaling and the presence of TGF- $\beta$ [196] and CTLA-4 costimulation, and it can be inhibited by IL-6 [20]. The role of Tregs and the TGF- $\beta$ pathway have also been investigated in lupus mice immunized with tolerogenic autoantigen-derived peptides [197-200]. Mice administered in tolerogenic regimens with a synthetic peptide from the $\mathrm{V}_{\mathrm{H}}$ regions of anti-DNA antibodies show delayed production of autoantibodies, nephritis and survive longer than control groups [201, 202]. This protection was dependent on the generation of both Tregs and $\mathrm{CD}^{+}$inhibitory T cells which secreted TGF- $\beta$ and suppressed anti-DNA Ig and IFN- $\gamma$ production [197-200, 203]. Similarly, the immunization of NZB/W $\mathrm{F}_{1}$ mice with an anti-DNA Ig-derived peptide called hCDR1 [204] ameliorated the serological and clinical manifestations of lupus [205]. The beneficial effects induced by hCDR 1 also correlated with an upregulation of TGF- $\beta$ and Tregs, and the down-regulation of IFN- $\gamma$ and IL-10. Moreover, Tregs suppressed lupus by down-regulating effector CD4 T cells activation and by upregulating the secretion of TGF- $\beta$ [206]. Other studies of tolerance induction in lupus-prone mice demonstrated that low dose of nucleosomal histone peptide decreased autoantibody levels and prolonged mice survival by delaying nephritis and by producing TGF- $\beta$ and inducing nucleosome-specific Tregs that suppressed CD4 T cells and 
autoantibody-producing B cells [199, 207] but also Th17 cells [42]. TGF- $\beta$ was produced after tolerance induction by pDC and inhibited IL- 6 production. The beneficial effects of TGF- $\beta$ could be partly ascribed to the ability of this cytokine to induce T-cell anergy via upregulation of negative regulators and downregulating protein kinases phosphorylation in $\mathrm{T}$ cells $[208,209]$.

\section{IL-6}

IL-6, an acute phase protein induced during inflammation, was first described as a B-cell stimulatory factor [210], but it affects many additional biological functions, including B-cell differentiation and maturation, Ig secretion, cytotoxic T-cell differentiation, acute-phase protein production, bone marrow progenitor stimulation, renal mesangial cell proliferation, and macrophage/monocyte functions [211-213]. More recent finding describe IL-6 as a key factor in the generation of Th17 cells [214] and a pivotal function in the inhibition of Tregs [20-22, 215].

Macrophages and monocytes are the main producers of IL-6 [216], but also T and B cells can produce this cytokine [217]. IL-6 mediates its biological activity through the binding to a receptor complex (IL-6Ra) and triggers the dimerization of the signal-transducing protein gp130, resulting in the activation of the Jak/STAT signal transduction pathway, where STAT3 is the most important in transmitting cytokine signals from the membrane to the nucleus [218]. Incidentally, T cells from SLE patients have increased levels of total and phosphorylated STAT3 associated with an increased expression of target genes, and the inhibition of STAT3 expression may reverse the signaling aberrations involved in T cell migration in SLE [219]. The suggestion that STAT3 may possibly play a key role in renal inflammation and fibrosis also comes from the finding that STAT3 is activated in normal human kidney and is markedly increased in many forms of glomerulonephritis, where its activation correlates with clinical and histologic parameters [220].

IL-6 can acts alone or with other cytokines to activate the differentiation process of B cells into Ig-producing cells, as well as the T cells proliferation and differentiation [221, 222]. IL-6 plays a critical role in the host immune responses against pathogens and several studies have been reported your involvement in various autoimmune diseases, such as SLE, RA, juvenile idiopathic arthritis and Crohn's disease [223, 224].

Elevated levels of IL-6 in serum, urine and renal glomeruli in patients with active SLE and in murine models of SLE suggest that IL-6 plays a role in lupus pathogenesis [223-226]. T and B cells are the main producers of IL-6 in patients with SLE, although IL-6 is also detected in monocytes from these patients [227]. Finally, SLE B cells are hypersensitive to IL-6 and production of anti-dsDNA autoantibodies can be blocked by anti-IL-6 mAb [227].

In murine lupus, the increase of serum IL-6 levels in MRL/lpr directly correlates with autoimmune disease progression and animal age, a finding not seen in normal mouse strains [228]. In the sera of MRL/lpr mice as young as 3 weeks of age, it is possible to detect IL-6 activity, and IL-6 mRNA expression is detected in the spleen and lymphonodes since 8 postnatal weeks [229]. In lupus-prone NZB/W F1 mice, serum IL-6 levels are elevated, and B cells are hyperresponsive to IL-6 [230]. The ability of B cells to produce IgG anti-DNA antibodies seems to be related to the expression levels of IL-6R at the age when the mice begin to develop the disease [231]. This observation is in concordance with studies that demonstrated abnormal cytokine production before the disease, including IL-6, in macrophages from different lupus-prone mouse strains [232, 233], suggesting that polyclonal B-cell activation in these mice is intrinsic to B-cell abnormalities. Also, IL-6 transgenic mice had increased autoantibody production and mesangial cell proliferative glomerulonephritis [234], and hypergammaglobulinemia was observed in mice that received 
cells expressing IL-6 [235]. Finally, NZB/W F1 mice treated with IL-6 developed an accelerated and severe form of membranoproliferative glomerulonephritis [236]. Conversely, treatment of NZB/W F1 mice with anti-IL-6 or with anti-IL-6R antibodies reduced $\mathrm{B}$-cell proliferation and the production of anti-dsDNA antibodies, proteinuria, and increased mice survival [237, 238].

Taken together, these studies support an abnormal function of IL-6/IL-6R and abnormal B cell activation in SLE, in addition to the role of IL-6 on Th17 differentiation and Treg suppression.

\section{CONCLUSION}

In SLE, the immune imbalance that characterizes the chronic autoimmune condition is associated with multiple abnormalities in the production and/or activity of several cytokines. While a pro-pathogenic role for certain cytokines has been established, the role of other cytokines in SLE is still debated and object of intense investigations. Fortunately, the past few years have seen the implementation of translational approaches specifically targeting cytokines in SLE to modulate the disease activity/progression in ongoing clinical trials. Some of these studies have given encouraging results and may possibly hold promising results for the near future. The hope is that cytokine-based therapies may become a useful complement in the management of SLE, which despite the great progresses in the past decades still remains an incurable disease.

\section{Acknowledgments}

A.L.C. is supported by the National Institutes of Health and the Arthritis Foundation Southern California Chapter. E.V.L. is supported by the Arthritis National Research Foundation.

\section{REFERENCES}

[1]. Tada T, Takemori T, Okumura K, Nonaka M, Tokuhisa T. J. Exp. Med. 1978; 147:446-458. [PubMed: 415110]

[2]. Wierenga EA, Snoek M, de Groot C, Chretien I, Bos JD, Jansen HM, Kapsenberg ML. J. Immunol. 1990; 144:4651-4656. [PubMed: 1972164]

[3]. Parronchi P, Macchia D, Piccinni MP, Biswas P, Simonelli C, Maggi E, Ricci M, Ansari AA, Romagnani S. Proc. Natl. Acad. Sci. USA. 1991; 88:4538-4542. [PubMed: 1827920]

[4]. Mosmann T. Nat. Immunol. 2000; 1:465-466. [PubMed: 11101865]

[5]. Harris DP, Haynes L, Sayles PC, Duso DK, Eaton SM, Lepak NM, Johnson LL, Swain SL, Lund FE. Nat. Immunol. 2000; 1:475-482. [PubMed: 11101868]

[6]. Liblau RS, Singer SM, McDevitt HO. Immunol. Today. 1995; 16:34-38. [PubMed: 7880387]

[7]. Constant SL, Bottomly K. Annu. Rev. Immunol. 1997; 15:297-322. [PubMed: 9143690]

[8]. Gajewski TF, Fitch FW. J. Immunol. 1988; 140:4245-4252. [PubMed: 2967332]

[9]. Fernandez-Botran R, Sanders VM, Mosmann TR, Vitetta ES. J. Exp. Med. 1988; 168:543-558. [PubMed: 2970518]

[10]. Liew FY. Nat. Rev. Immunol. 2002; 2:55-60. [PubMed: 11905838]

[11]. Swain SL, Weinberg AD, English M, Huston G. J. Immunol. 1990; 145:3796-3806. [PubMed: 2147202]

[12]. Le Gros G, Ben-Sasson SZ, Seder R, Finkelman FD, Paul WE. J. Exp. Med. 1990; 172:921-929. [PubMed: 2117636]

[13]. Hsieh CS, Macatonia SE, Tripp CS, Wolf SF, O’Garra A, Murphy KM. Science. 1993; 260:547549. [PubMed: 8097338]

[14]. Szabo SJ, Kim ST, Costa GL, Zhang X, Fathman CG, Glimcher LH. Cell. 2000; 100:655-669. [PubMed: 10761931] 
[15]. Kaplan MH, Schindler U, Smiley ST, Grusby MJ. Immunity. 1996; 4:313-319. [PubMed: 8624821]

[16]. Takeda K, Tanaka T, Shi W, Matsumoto M, Minami M, Kashiwamura S, Nakanishi K, Yoshida N, Kishimoto T, Akira S. Nature. 1996; 380:627-630. [PubMed: 8602263]

[17]. Shimoda K, van Deursen J, Sangster MY, Sarawar SR, Carson RT, Tripp RA, Chu C, Quelle FW, Nosaka T, Vignali DA, Doherty PC, Grosveld G, Paul WE, Ihle JN. Nature. 1996; 380:630633. [PubMed: 8602264]

[18]. Furuzawa-Carballeda J, Vargas-Rojas MI, Cabral AR. Autoimmun. Rev. 2007; 6:169-175. [PubMed: 17289553]

[19]. Wu Y, Borde M, Heissmeyer V, Feuerer M, Lapan AD, Stroud JC, Bates DL, Guo L, Han A, Ziegler SF, Mathis D, Benoist C, Chen L, Rao A. Cell. 2006; 126:375-387. [PubMed: 16873067]

[20]. Bettelli E, Carrier Y, Gao W, Korn T, Strom TB, Oukka M, Weiner HL, Kuchroo VK. Nature. 2006; 441:235-238. [PubMed: 16648838]

[21]. Mangan PR, Harrington LE, O'Quinn DB, Helms WS, Bullard DC, Elson CO, Hatton RD, Wahl SM, Schoeb TR, Weaver CT. Nature. 2006; 441:231-234. [PubMed: 16648837]

[22]. Veldhoen M, Hocking RJ, Atkins CJ, Locksley RM, Stockinger B. Immunity. 2006; 24:179-189. [PubMed: 16473830]

[23]. Sakaguchi S. Cell. 2000; 101:455-458. [PubMed: 10850488]

[24]. Shevach EM. Annu. Rev. Immunol. 2000; 18:423-449. [PubMed: 10837065]

[25]. Sakaguchi S, Sakaguchi N, Asano M, Itoh M, Toda M. J. Immunol. 1995; 155:1151-1164. [PubMed: 7636184]

[26]. Crispin JC, Martinez A, Alcocer-Varela J. J. Autoimmun. 2003; 21:273-276. [PubMed: 14599852]

[27]. Liu MF, Wang CR, Fung LL, Wu CR. Scand. J. Immunol. 2004; 59:198-202. [PubMed: 14871297]

[28]. La Cava A, Ebling FM, Hahn BH. J. Immunol. 2004; 173:3542-3548. [PubMed: 15322219]

[29]. Valencia X, Yarboro C, Illei G, Lipsky PE. J. Immunol. 2007; 178:2579-2588. [PubMed: 17277168]

[30]. Miyara M, Amoura Z, Parizot C, Badoual C, Dorgham K, Trad S, Nochy D, Debre P, Piette JC, Gorochov G. J. Immunol. 2005; 175:8392-8400. [PubMed: 16339581]

[31]. Scalapino KJ, Tang Q, Bluestone JA, Bonyhadi ML, Daikh DI. J. Immunol. 2006; 177:14511459. [PubMed: 16849451]

[32]. Hayashi T, Hasegawa K, Adachi C. Int. J. Exp. Pathol. 2005; 86:289-296. [PubMed: 16191101]

[33]. Weaver CT, Harrington LE, Mangan PR, Gavrieli M, Murphy KM. Immunity. 2006; 24:677688. [PubMed: 16782025]

[34]. Druet P, Sheela R, Pelletier L. Clin. Exp. Immunol. 1995; 101:9-12. [PubMed: 7606862]

[35]. Steinman RM. Annu. Rev. Immunol. 1991; 9:271-296. [PubMed: 1910679]

[36]. Banchereau J, Briere F, Caux C, Davoust J, Lebecque S, Liu YJ, Pulendran B, Palucka K. Annu. Rev. Immunol. 2000; 18:767-811. [PubMed: 10837075]

[37]. Dubois B, Vanbervliet B, Fayette J, Massacrier C, Van Kooten C, Briere F, Banchereau J, Caux C. J. Exp. Med. 1997; 185:941-951. [PubMed: 9120400]

[38]. Fayette J, Durand I, Bridon JM, Arpin C, Dubois B, Caux C, Liu YJ, Banchereau J, Briere F. Scand. J. Immunol. 1998; 48:563-570. [PubMed: 9874489]

[39]. Blanco P, Palucka AK, Gill M, Pascual V, Banchereau J. Science. 2001; 294:1540-1543. [PubMed: 11711679]

[40]. Wan S, Xia C, Morel L. J. Immunol. 2007; 178:271-279. [PubMed: 17182564]

[41]. Gutcher I, Becher B. J. Clin. Invest. 2007; 117:1119-1127. [PubMed: 17476341]

[42]. Kang HK, Liu M, Datta SK. J. Immunol. 2007; 178:7849-7858. [PubMed: 17548623]

[43]. Klinman DM, Steinberg AD. J. Exp. Med. 1987; 165:1755-1760. [PubMed: 3495631]

[44]. Casciola-Rosen LA, Anhalt G, Rosen A. J. Exp. Med. 1994; 179:1317-1330. [PubMed: 7511686]

[45]. Cocca BA, Cline AM, Radic MZ. J. Immunol. 2002; 169:159-166. [PubMed: 12077241] 
[46]. Herrmann M, Voll RE, Kalden JR. Immunol. Today. 2000; 21:424-426. [PubMed: 10953093]

[47]. Chernysheva AD, Kirou KA, Crow MK. J. Immunol. 2002; 169:1241-1250. [PubMed: 12133945]

[48]. Cheema GS, Roschke V, Hilbert DM, Stohl W. Arthritis Rheum. 2001; 44:1313-1319. [PubMed: 11407690]

[49]. Stohl W, Metyas S, Tan SM, Cheema GS, Oamar B, Xu D, Roschke V, Wu Y, Baker KP, Hilbert DM. Arthritis Rheum. 2003; 48:3475-3486. [PubMed: 14673998]

[50]. Baker KP. Autoimmun. Rev. 2004; 3:368-375. [PubMed: 15288003]

[51]. Ferrera F, Hahn BH, Rizzi M, Anderson M, Fitzgerald J, Millo E, Indiveri F, Shi FD, Filaci G, La Cava A. Arthritis Rheum. 2007; 56:1945-1953. [PubMed: 17530718]

[52]. Funauchi M, Ikoma S, Enomoto H, Horiuchi A. Scand. J. Rheumatol. 1998; 27:219-224. [PubMed: 9645418]

[53]. Min DJ, Cho ML, Cho CS, Min SY, Kim WU, Yang SY, Min JK, Hong YS, Lee SH, Park SH, Kim WY. Scand. J. Rheumatol. 2001; 30:159-163. [PubMed: 11469526]

[54]. Grondal G, Gunnarsson I, Ronnelid J, Rogberg S, Klareskog L, Lundberg I. Clin. Exp. Rheumatol. 2000; 18:565-570. [PubMed: 11072595]

[55]. Greig PC, Herbert WN, Robinette BL, Teot LA. Am. J. Obstet. Gynecol. 1995; 173:1223-1227. [PubMed: 7485325]

[56]. Doria A, Iaccarino L, Arienti S, Ghirardello A, Zampieri S, Rampudda ME, Cutolo M, Tincani A, Todesco S. Reprod. Toxicol. 2006; 22:234-241. [PubMed: 16704920]

[57]. Gomez D, Correa PA, Gomez LM, Cadena J, Molina JF, Anaya JM. Semin. Arthritis Rheum. 2004; 33:404-413. [PubMed: 15190525]

[58]. Enghard P, Langnickel D, Riemekasten G. Scand. J. Rheumatol. 2006; 35:209-216. [PubMed: 16766368]

[59]. Jacob CO, van der Meide PH, McDevitt HO. J. Exp. Med. 1987; 166:798-803. [PubMed: 3114409]

[60]. Ozmen L, Roman D, Fountoulakis M, Schmid G, Ryffel B, Garotta G. Eur. J. Immunol. 1995; 25:6-12. [PubMed: 7843255]

[61]. Ishida H, Muchamuel T, Sakaguchi S, Andrade S, Menon S, Howard M. J. Exp. Med. 1994; 179:305-310. [PubMed: 8270873]

[62]. Peng SL, Moslehi J, Craft J. J. Clin. Invest. 1997; 99:1936-1946. [PubMed: 9109438]

[63]. Prud'homme GJ, Kono DH, Theofilopoulos AN. Mol. Immunol. 1995; 32:495-503. [PubMed: 7783752]

[64]. Takahashi S, Fossati L, Iwamoto M, Merino R, Motta R, Kobayakawa T, Izui S. J. Clin. Invest. 1996; 97:1597-1604. [PubMed: 8601623]

[65]. Huang FP, Feng GJ, Lindop G, Stott DI, Liew FY. J. Exp. Med. 1996; 183:1447-1459. [PubMed: 8666903]

[66]. Schorlemmer HU, Dickneite G, Kanzy EJ, Enssle KH. Inflamm. Res. 1995; 44:S194-196. [PubMed: 8548394]

[67]. Nicoletti F, Meroni P, Di Marco R, Barcellini W, Borghi MO, Gariglio M, Mattina A, Grasso S, Landolfo S. Immunopharmacology. 1992; 24:11-16. [PubMed: 1452442]

[68]. Kaplan MH, Sun YL, Hoey T, Grusby MJ. Nature. 1996; 382:174-177. [PubMed: 8700209]

[69]. Singh RR, Saxena V, Zang S, Li L, Finkelman FD, Witte DP, Jacob CO. J. Immunol. 2003; 170:4818-4825. [PubMed: 12707364]

[70]. Remmers EF, Plenge RM, Lee AT, Graham RR, Hom G, Behrens TW, de Bakker PI, Le JM, Lee HS, Batliwalla F, Li W, Masters SL, Booty MG, Carulli JP, Padyukov L, Alfredsson L, Klareskog L, Chen WY, Amos CI, Criswell LA, Seldin MF, Kastner DL, Gregersen PK. N. Engl. J. Med. 2007; 357:977-986. [PubMed: 17804842]

[71]. Medzhitov R, Preston-Hurlburt P, Janeway CA Jr. Nature. 1997; 388:394-397. [PubMed: 9237759]

[72]. Crow M, Kiroua K 7th. Wallace DJ, Hahn BH. Dubois' Lupus Erythematosus. 2007:161-175. 
[73]. Adachi O, Kawai T, Takeda K, Matsumoto M, Tsutsui H, Sakagami M, Nakanishi K, Akira S. Immunity. 1998; 9:143-150. [PubMed: 9697844]

[74]. Sadanaga A, Nakashima H, Akahoshi M, Masutani K, Miyake K, Igawa T, Sugiyama N, Niiro H, Harada M. Arthritis Rheum. 2007; 56:1618-1628. [PubMed: 17469144]

[75]. Kawai T, Adachi O, Ogawa T, Takeda K, Akira S. Immunity. 1999; 11:115-122. [PubMed: 10435584]

[76]. Pasare C, Medzhitov R. Science. 2003; 299:1033-1036. [PubMed: 12532024]

[77]. Rui L, Vinuesa CG, Blasioli J, Goodnow CC. Nat. Immunol. 2003; 4:594-600. [PubMed: 12740574]

[78]. Anders HJ, Vielhauer V, Eis V, Linde Y, Kretzler M, Perez de Lema G, Strutz F, Bauer S, Rutz M, Wagner H, Grone HJ, Schlondorff D. FASEB J. 2004; 18:534-536. [PubMed: 14734643]

[79]. Pawar RD, Patole PS, Zecher D, Segerer S, Kretzler M, Schlondorff D, Anders HJ. J. Am. Soc. Nephrol. 2006; 17:141-149. [PubMed: 16280469]

[80]. Leadbetter EA, Rifkin IR, Hohlbaum AM, Beaudette BC, Shlomchik MJ, Marshak-Rothstein A. Nature. 2002; 416:603-607. [PubMed: 11948342]

[81]. Vollmer J, Tluk S, Schmitz C, Hamm S, Jurk M, Forsbach A, Akira S, Kelly KM, Reeves WH, Bauer S, Krieg AM. J. Exp. Med. 2005; 202:1575-1585. [PubMed: 16330816]

[82]. Lau CM, Broughton C, Tabor AS, Akira S, Flavell RA, Mamula MJ, Christensen SR, Shlomchik MJ, Viglianti GA, Rifkin IR, Marshak-Rothstein A. J. Exp. Med. 2005; 202:1171-1177. [PubMed: 16260486]

[83]. Patole PS, Grone HJ, Segerer S, Ciubar R, Belemezova E, Henger A, Kretzler M, Schlondorff D, Anders HJ. J. Am. Soc. Nephrol. 2005; 16:1326-1338. [PubMed: 15772251]

[84]. Rozzo SJ, Allard JD, Choubey D, Vyse TJ, Izui S, Peltz G, Kotzin BL. Immunity. 2001; 15:435443. [PubMed: 11567633]

[85]. Yamauchi M, Hashimoto M, Ichiyama K, Yoshida R, Hanada T, Muta T, Komune S, Kobayashi T, Yoshimura A. Int. Immunol. 2007; 19:935-942. [PubMed: 17702989]

[86]. Choubey D, Kotzin BL. Front. Biosci. 2002; 7:252-262.

[87]. Fitzgerald-Bocarsly P. Pharmacol. Ther. 1993; 60:39-62. [PubMed: 8127923]

[88]. Siegal FP, Kadowaki N, Shodell M, Fitzgerald-Bocarsly PA, Shah K, Ho S, Antonenko S, Liu YJ. Science. 1999; 284:1835-1837. [PubMed: 10364556]

[89]. Ronnblom L, Alm GV. Arthritis Res. Ther. 2003; 5:68-75. [PubMed: 12718746]

[90]. Steinman RM, Hawiger D, Nussenzweig MC. Annu. Rev. Immunol. 2003; 21:685-711. [PubMed: 12615891]

[91]. Banchereau J, Pascual V, Palucka AK. Immunity. 2004; 20:539-550. [PubMed: 15142523]

[92]. Ronnblom L, Alm GV. Trends Immunol. 2001; 22:427-431. [PubMed: 11473831]

[93]. Granucci F, Zanoni I. Front. Biosci. 2008; 13:4817-26. [PubMed: 18508547]

[94]. Braun D, Geraldes P, Demengeot J. J. Autoimmun. 2003; 20:15-25. [PubMed: 12604309]

[95]. Santiago-Raber ML, Baccala R, Haraldsson KM, Choubey D, Stewart TA, Kono DH, Theofilopoulos AN. J. Exp. Med. 2003; 197:777-788. [PubMed: 12642605]

[96]. Mathian A, Weinberg A, Gallegos M, Banchereau J, Koutouzov S. J. Immunol. 2005; 174:2499_ 2506. [PubMed: 15728455]

[97]. Hron JD, Peng SL. J. Immunol. 2004; 173:2134-2142. [PubMed: 15265950]

[98]. Hooks JJ, Moutsopoulos HM, Geis SA, Stahl NI, Decker JL, Notkins ALM. N. Engl. J. Med. 1979; 301:5-8. [PubMed: 449915]

[99]. Hooks JJ, Jordan GW, Cupps T, Moutsopoulos HM, Fauci AS, Notkins AL. Arthritis Rheum. 1982; 25:396-400. [PubMed: 6176247]

[100]. Kim T, Kanayama Y, Negoro N, Okamura M, Takeda T, Inoue T. Clin. Exp. Immunol. 1987; 70:562-569. [PubMed: 2449306]

[101]. Bengtsson AA, Sturfelt G, Truedsson L, Blomberg J, Alm G, Vallin H, Ronnblom L. Lupus. 2000; 9:664-671. [PubMed: 11199920]

[102]. Ronnblom LE, Alm GV, Oberg KE. J. Intern. Med. 1990; 227:207-210. [PubMed: 1690258] 
[103]. Zhang ZX, Milich DR, Peterson DL, Birkett A, Schvarcz R, Weiland O, Sallberg M. J. Infect. Dis. 1997; 175:1294-1301. [PubMed: 9180166]

[104]. Niewold TB, Hua J, Lehman TJ, Harley JB, Crow MK. Genes Immun. 2007; 8:492-502. [PubMed: 17581626]

[105]. Crow MK, Kirou KA, Wohlgemuth J. Autoimmunity. 2003; 36:481-490. [PubMed: 14984025]

[106]. Kozyrev SV, Alarcon-Riquelme ME. Autoimmunity. 2007; 40:591-601. [PubMed: 18075793]

[107]. Kirou KA, Lee C, George S, Louca K, Papagiannis IG, Peterson MG, Ly N, Woodward RN, Fry KE, Lau AY, Lau AY, Prentice JG, Wohlgemuth JG, Crow MK. Arthritis Rheum. 2004; 50:3958-3967. [PubMed: 15593221]

[108]. Belardelli F. APMIS. 1995; 103:161-179. [PubMed: 7538771]

[109]. Theofilopoulos AN, Koundouris S, Kono DH, Lawson BR. Arthritis Res. 2001; 3:136-141. [PubMed: 11299053]

[110]. Akahoshi M, Nakashima H, Tanaka Y, Kohsaka T, Nagano S, Ohgami E, Arinobu Y, Yamaoka K, Niiro H, Shinozaki M, Hirakata H, Horiuchi T, Otsuka T, Niho Y. Arthritis Rheum. 1999; 42:1644-1648. [PubMed: 10446863]

[111]. Haas C, Ryffel B, Le Hir M. J. Immunol. 1998; 160:3713-3718. [PubMed: 9558072]

[112]. Lawson BR, Prud'homme GJ, Chang Y, Gardner HA, Kuan J, Kono DH, Theofilopoulos AN. J. Clin. Invest. 2000; 106:207-215. [PubMed: 10903336]

[113]. Balomenos D, Rumold R, Theofilopoulos AN. J. Clin. Invest. 1998; 101:364-371. [PubMed: 9435308]

[114]. Manolios N, Schrieber L, Nelson M, Geczy CL. Clin. Exp. Immunol. 1989; 76:301-306. [PubMed: 2503279]

[115]. Seery JP, Carroll JM, Cattell V, Watt FM. J. Exp. Med. 1997; 186:1451-1459. [PubMed: 9348302]

[116]. Dong J, Wang QX, Zhou CY, Ma XF, Zhang YC. Lupus. 2007; 16:101-109. [PubMed: 17402366]

[117]. Martinez-Lostao L, Ordi-Ros J, Balada E, Segarra-Medrano A, Majo-Masferrer J, LabradorHorrillo M, Vilardell-Tarres M. Lupus. 2007; 16:483-488. [PubMed: 17670846]

[118]. Refaeli Y, Van Parijs L, London CA, Tschopp J, Abbas AK. Immunity. 1998; 8:615-623. [PubMed: 9620682]

[119]. Abbas AK. Autoimmun. Rev. 2003; 2:115-118. [PubMed: 12848951]

[120]. Iliopoulos AG, Tsokos GC. Semin. Arthritis Rheum. 1996; 25:318-336. [PubMed: 8778988]

[121]. Laurence A, Tato CM, Davidson TS, Kanno Y, Chen Z, Yao Z, Blank RB, Meylan F, Siegel R, Hennighausen L, Shevach EM, O'shea JJ. Immunity. 2007; 26:371-381. [PubMed: 17363300]

[122]. Suzuki H, Kundig TM, Furlonger C, Wakeham A, Timms E, Matsuyama T, Schmits R, Simard JJ, Ohashi PS, Griesser H, et al. Science. 1995; 268:1472-1476. [PubMed: 7770771]

[123]. Alcocer-Varela J, Alarcon-Segovia D. J. Clin. Invest. 1982; 69:1388-1392. [PubMed: 6979554]

[124]. Linker-Israeli M, Bakke AC, Kitridou RC, Gendler S, Gillis S, Horwitz DA. J. Immunol. 1983; 130:2651-2655. [PubMed: 6222112]

[125]. Theofilopoulos AN, Dixon FJ. Adv. Immunol. 1985; 37:269-390. [PubMed: 3890479]

[126]. Solomou EE, Juang YT, Gourley MF, Kammer GM, Tsokos GC. J. Immunol. 2001; 166:42164222. [PubMed: 11238674]

[127]. Miyagi J, Minato N, Sumiya M, Kasahara T, Kano S. Arthritis Rheum. 1989; 32:1356-1364. [PubMed: 2684169]

[128]. Juang YT, Wang Y, Solomou EE, Li Y, Mawrin C, Tenbrock K, Kyttaris VC, Tsokos GC. J. Clin. Invest. 2005; 115:996-1005. [PubMed: 15841182]

[129]. Ishida H, Kumagai S, Umehara H, Sano H, Tagaya Y, Yodoi J, Imura H. J. Immunol. 1987; 139:1070-1074. [PubMed: 3112222]

[130]. Wolf RE, Brelsford WG. Arthritis Rheum. 1988; 31:729-735. [PubMed: 3132927]

[131]. Manoussakis MN, Germanidis GS, Drosos AA, Moutsopoulos HM. Lupus. 1992; 1:105-109. [PubMed: 1301961] 
[132]. Bertagnolli MM, Lin BY, Young D, Herrmann SH. J. Immunol. 1992; 149:3778-3783. [PubMed: 1360994]

[133]. Chan SH, Perussia B, Gupta JW, Kobayashi M, Pospisil M, Young HA, Wolf SF, Young D, Clark SC, Trinchieri G. J. Exp. Med. 1991; 173:869-879. [PubMed: 1672545]

[134]. Tokano Y, Morimoto S, Kaneko H, Amano H, Nozawa K, Takasaki Y, Hashimoto H. Clin. Exp. Immunol. 1999; 116:169-173. [PubMed: 10209522]

[135]. Liu TF, Jones BM, Wong RW, Srivastava G. Cytokine. 1999; 11:805-811. [PubMed: 10525320]

[136]. Lauwerys BR, Van Snick J, Houssiau FA. Lupus. 2002; 11:384-387. [PubMed: 12139377]

[137]. Fan X, Oertli B, Wuthrich RP. Kidney Int. 1997; 51:79-86. [PubMed: 8995720]

[138]. Schwarting A, Tesch G, Kinoshita K, Maron R, Weiner HL, Kelley VR. J. Immunol. 1999; 163:6884-6891. [PubMed: 10586090]

[139]. Kikawada E, Lenda DM, Kelley VR. J. Immunol. 2003; 170:3915-3925. [PubMed: 12646661]

[140]. Okamura H, Tsutsi H, Komatsu T, Yutsudo M, Hakura A, Tanimoto T, Torigoe K, Okura T, Nukada Y, Hattori K, Akita K, Namba M, Tanabe F, Konishi K, Fukuda S, Kurimoto M. Nature. 1995; 378:88-91. [PubMed: 7477296]

[141]. Kohno K, Kataoka J, Ohtsuki T, Suemoto Y, Okamoto I, Usui M, Ikeda M, Kurimoto M. J. Immunol. 1997; 158:1541-1550. [PubMed: 9029088]

[142]. Faust J, Menke J, Kriegsmann J, Kelley VR, Mayet WJ, Galle PR, Schwarting A. Arthritis Rheum. 2002; 46:3083-3095. [PubMed: 12428253]

[143]. Esfandiari E, McInnes IB, Lindop G, Huang FP, Field M, Komai-Koma M, Wei X, Liew FY. J. Immunol. 2001; 167:5338-5347. [PubMed: 11673550]

[144]. Calvani N, Richards HB, Tucci M, Pannarale G, Silvestris F. Clin. Exp. Immunol. 2004; 138:171-178. [PubMed: 15373921]

[145]. Calvani N, Tucci M, Richards HB, Tartaglia P, Silvestris F. Autoimmun. Rev. 2005; 4:542-548. [PubMed: 16214093]

[146]. Amerio P, Frezzolini A, Abeni D, Teofoli P, Girardelli CR, De Pita O, Puddu P. Clin. Exp. Rheumatol. 2002; 20:535-538. [PubMed: 12175109]

[147]. Hunter CA. Nat. Rev. Immunol. 2005; 5:521-531. [PubMed: 15999093]

[148]. Oppmann B, Lesley R, Blom B, Timans JC, Xu Y, Hunte B, Vega F, Yu N, Wang J, Singh K, Liu M, Gorman D, Wagner J, Zurawski S, Liu Y, Abrams JS, Moore KW, Rennick D, de WaalMalefyt R, Hannum C, Bazan JF, Kastelein RA. Immunity. 2000; 13:715-725. [PubMed: 11114383]

[149]. Langrish CL, Chen Y, Blumenschein WM, Mattson J, Basham B, Sedgwick JD, McClanahan T, Kastelein RA, Cua DJ. J. Exp. Med. 2005; 201:233-240. [PubMed: 15657292]

[150]. Murphy CA, Langrish CL, Chen Y, Blumenschein W, McClanahan T, Kastelein RA, Sedgwick JD, Cua DJ. J. Exp. Med. 2003; 198:1951-1957. [PubMed: 14662908]

[151]. McKenzie BS, Kastelein RA, Cua DJ. Trends Immunol. 2006; 27:17-23. [PubMed: 16290228]

[152]. Holscher C, Atkinson RA, Arendse B, Brown N, Myburgh E, Alber G, Brombacher F. J. Immunol. 2001; 167:6957-6966. [PubMed: 11739515]

[153]. Lehmann J, Bellmann S, Werner C, Schroder R, Schutze N, Alber G. J. Immunol. 2001; 167:5304-5315. [PubMed: 11673546]

[154]. Cua DJ, Sherlock J, Chen Y, Murphy CA, Joyce B, Seymour B, Lucian L, To W, Kwan S, Churakova T, Zurawski S, Wiekowski M, Lira SA, Gorman D, Kastelein RA, Sedgwick JD. Nature. 2003; 421:744-748. [PubMed: 12610626]

[155]. Lieberman LA, Cardillo F, Owyang AM, Rennick DM, Cua DJ, Kastelein RA, Hunter CA. J. Immunol. 2004; 173:1887-1893. [PubMed: 15265921]

[156]. Kikly K, Liu L, Na S, Sedgwick JD. Curr. Opin. Immunol. 2006; 18:670-675. [PubMed: 17010592]

[157]. Huang X, Hua J, Shen N, Chen S. Mod. Rheumatol. 2007; 17:220-223. [PubMed: 17564777]

[158]. Fiorentino DF, Bond MW, Mosmann TR. J. Exp. Med. 1989; 170:2081-2095. [PubMed: 2531194] 
[159]. O’Garra A, Vieira P. Nat. Rev. Immunol. 2007; 7:425-428. [PubMed: 17525751]

[160]. Moore KW, de Waal Malefyt R, Coffman RL, O’Garra A. Annu. Rev. Immunol. 2001; 19:683765. [PubMed: 11244051]

[161]. Kuhn R, Lohler J, Rennick D, Rajewsky K, Muller W. Cell. 1993; 75:263-274. [PubMed: 8402911]

[162]. Berg DJ, Kuhn R, Rajewsky K, Muller W, Menon S, Davidson N, Grunig G, Rennick D. J. Clin. Invest. 1995; 96:2339-2347. [PubMed: 7593621]

[163]. Gazzinelli RT, Wysocka M, Hieny S, Scharton-Kersten T, Cheever A, Kuhn R, Muller W, Trinchieri G, Sher A. J. Immunol. 1996; 157:798-805. [PubMed: 8752931]

[164]. Roncarolo MG, Bacchetta R, Bordignon C, Narula S, Levings MK. Immunol. Rev. 2001; 182:68-79. [PubMed: 11722624]

[165]. Beebe AM, Cua DJ, de Waal Malefyt R. Cytokine Growth Factor Rev. 2002; 13:403-412. [PubMed: 12220553]

[166]. Rousset F, Garcia E, Defrance T, Peronne C, Vezzio N, Hsu DH, Kastelein R, Moore KW, Banchereau J. Proc. Natl. Acad. Sci. USA. 1992; 89:1890-1893. [PubMed: 1371884]

[167]. Llorente L, Richaud-Patin Y, Wijdenes J, Alcocer-Varela J, Maillot MC, Durand-Gasselin I, Fourrier BM, Galanaud P, Emilie D. Eur. Cytokine. Netw. 1993; 4:421-427. [PubMed: 8186374]

[168]. Llorente L, Richaud-Patin Y, Fior R, Alcocer-Varela J, Wijdenes J, Fourrier BM, Galanaud P, Emilie D. Arthritis Rheum. 1994; 37:1647-1655. [PubMed: 7980676]

[169]. Chun HY, Chung JW, Kim HA, Yun JM, Jeon JY, Ye YM, Kim SH, Park HS, Suh CH. J. Clin. Immunol. 2007; 27:461-466. [PubMed: 17587156]

[170]. Houssiau FA, Lefebvre C, Vanden Berghe M, Lambert M, Devogelaer JP, Renauld JC. Lupus. 1995; 4:393-395. [PubMed: 8563734]

[171]. Park YB, Lee SK, Kim DS, Lee J, Lee CH, Song CH. Clin. Exp. Rheumatol. 1998; 16:283-288. [PubMed: 9631750]

[172]. Georgescu L, Vakkalanka RK, Elkon KB, Crow MK. J. Clin. Invest. 1997; 100:2622-2633. [PubMed: 9366578]

[173]. Yin Z, Bahtiyar G, Zhang N, Liu L, Zhu P, Robert ME, McNiff J, Madaio MP, Craft J. J. Immunol. 2002; 169:2148-2155. [PubMed: 12165544]

[174]. Feldmann M, Maini RN. Annu. Rev. Immunol. 2001; 19:163-196. [PubMed: 11244034]

[175]. Haraoui B, Keystone E. Curr. Opin. Rheumatol. 2006; 18:96-100. [PubMed: 16344625]

[176]. Palucka AK, Blanck JP, Bennett L, Pascual V, Banchereau J. Proc. Natl. Acad. Sci. USA. 2005; 102:3372-3377. [PubMed: 15728381]

[177]. Bennett L, Palucka AK, Arce E, Cantrell V, Borvak J, Banchereau J, Pascual V. J. Exp. Med. 2003; 197:711-723. [PubMed: 12642603]

[178]. Studnicka-Benke A, Steiner G, Petera P, Smolen JS. Br. J. Rheumatol. 1996; 35:1067-1074. [PubMed: 8948291]

[179]. Boswell JM, Yui MA, Burt DW, Kelley VE. J. Immunol. 1988; 141:3050-3054. [PubMed: 3262676]

[180]. Brennan DC, Yui MA, Wuthrich RP, Kelley VE. J. Immunol. 143:3470-3475. 91989. [PubMed: 2584702]

[181]. Zhu L, Yang X, Chen W, Li X, Ji Y, Mao H, Nie J, Yu X. Clin. Rheumatol. 2007; 26:14811489. [PubMed: 17235653]

[182]. Alves-Rosa MF, Palermo MS, Isturiz MA. Clin. Immunol. Immunopathol. 1998; 89:214-221. [PubMed: 9837691]

[183]. Jacob CO, Hwang F, Lewis GD, Stall AM. Cytokine. 1991; 3:551-561. [PubMed: 1686413]

[184]. Murphy KM, Reiner SL. Nat. Rev. Immunol. 2002; 2:933-944. [PubMed: 12461566]

[185]. Happel KI, Dubin PJ, Zheng M, Ghilardi N, Lockhart C, Quinton LJ, Odden AR, Shellito JE, Bagby GJ, Nelson S, Kolls JK. J. Exp. Med. 2005; 202:761-769. [PubMed: 16157683]

[186]. Harrington LE, Hatton RD, Mangan PR, Turner H, Murphy TL, Murphy KM, Weaver CT. Nat. Immunol. 2005; 6:1123-1132. [PubMed: 16200070]

[187]. Schwandner R, Yamaguchi K, Cao Z. J. Exp. Med. 2000; 191:1233-1240. [PubMed: 10748240] 
[188]. Kolls JK, Linden A. Immunity. 2004; 21:467-476. [PubMed: 15485625]

[189]. Ye P, Rodriguez FH, Kanaly S, Stocking KL, Schurr J, Schwarzenberger P, Oliver P, Huang W, Zhang P, Zhang J, Shellito JF, Bagby GJ, Nelson S, Charrier K, Peschon JJ, Kolls JK. J. Exp. Med. 2001; 194:519-527. [PubMed: 11514607]

[190]. Nakae S, Komiyama Y, Nambu A, Sudo K, Iwase M, Homma I, Sekikawa K, Asano M, Iwakura Y. Immunity. 2002; 17:375-387. [PubMed: 12354389]

[191]. Park H, Li Z, Yang XO, Chang SH, Nurieva R, Wang YH, Wang Y, Hood L, Zhu Z, Tian Q, Dong C. Nat. Immunol. 2005; 6:1133-1141. [PubMed: 16200068]

[192]. Yagi H, Nomura T, Nakamura K, Yamazaki S, Kitawaki T, Hori S, Maeda M, Onodera M, Uchiyama T, Fujii S, Sakaguchi S. Int. Immunol. 2004; 16:1643-1656. [PubMed: 15466453]

[193]. Fontenot JD, Gavin MA, Rudensky AY. Nat. Immunol. 2003; 4:330-336. [PubMed: 12612578]

[194]. Khattri R, Cox T, Yasayko SA, Ramsdell F. Nat. Immunol. 2003; 4:337-342. [PubMed: 12612581]

[195]. La Cava A. Lupus. 2008; 17:421-425. [PubMed: 18490420]

[196]. La Cava A. Front. Biosci. In press.

[197]. Hahn BH, Singh RP, La Cava A, Ebling FM. J. Immunol. 2005; 175:7728-7737. [PubMed: 16301683]

[198]. Singh RR, Ebling FM, Albuquerque DA, Saxena V, Kumar V, Giannini EH, Marion TN, Finkelman FD, Hahn BH. J. Immunol. 2002; 169:587-594. [PubMed: 12077292]

[199]. Kang HK, Michaels MA, Berner BR, Datta SK. J. Immunol. 2005; 174:3247-3255. [PubMed: 15749855]

[200]. Sela U, Hershkoviz R, Cahalon L, Lider O, Mozes E. J. Immunol. 2005; 174:302-309. [PubMed: 15611253]

[201]. Singh RR, Ebling FM, Sercarz EE, Hahn BH. J. Clin. Invest. 1995; 96:2990-2996. [PubMed: 8675671]

[202]. Hahn BH, Singh RR, Wong WK, Tsao BP, Bulpitt K, Ebling FM. Arthritis Rheum. 2001; 44:432-441. [PubMed: 11229475]

[203]. Singh RP, La Cava A, Wong M, Ebling F, Hahn BH. J. Immunol. 2007; 178:7649-7657. [PubMed: 17548601]

[204]. Waisman A, Shoenfeld Y, Blank M, Ruiz PJ, Mozes E. Int. Immunol. 1995; 7:689-696. [PubMed: 7547696]

[205]. Luger D, Dayan M, Zinger H, Liu JP, Mozes E. J. Clin. Immunol. 2004; 24:579-590. [PubMed: 15622442]

[206]. Sharabi A, Zinger H, Zborowsky M, Sthoeger ZM, Mozes E. Proc. Natl. Acad. Sci. USA. 2006; 103:8810-8815. [PubMed: 16735466]

[207]. Kang HK, Datta SK. Int. Rev. Immunol. 2006; 25:5-25. [PubMed: 16531276]

[208]. Sela U, Dayan M, Hershkoviz R, Cahalon L, Lider O, Mozes E. Eur. J. Immunol. 2006; 36:2971-2980. [PubMed: 17051618]

[209]. Sela U, Dayan M, Hershkoviz R, Lider O, Mozes E. J. Immunol. 2008; 180:1584-1591. [PubMed: 18209054]

[210]. Kishimoto T. Annu. Rev. Immunol. 2005; 23:1-21. [PubMed: 15771564]

[211]. Muraguchi A, Hirano T, Tang B, Matsuda T, Horii Y, Nakajima K, Kishimoto T. J. Exp. Med. 1988; 167:332-344. [PubMed: 3258006]

[212]. Wong GG, Witek-Giannotti JS, Temple PA, Kriz R, Ferenz C, Hewick RM, Clark SC, Ikebuchi K, Ogawa M. J. Immunol. 1988; 140:3040-3044. [PubMed: 3258892]

[213]. Horii Y, Iwano M, Hirata E, Shiiki M, Fujii Y, Dohi K, Ishikawa H. Kidney Int. Suppl. 1993; 39:S71-75. [PubMed: 8468929]

[214]. Weaver CT, Hatton RD, Mangan PR, Harrington LE. Annu. Rev. Immunol. 2007; 25:821-852. [PubMed: 17201677]

[215]. Veldhoen M, Hocking RJ, Flavell RA, Stockinger B. Nat. Immunol. 2006; 7:1151-1156. [PubMed: 16998492] 
[216]. Baumann H, Jahreis GP, Sauder DN, Koj A. J. Biol. Chem. 1984; 259:7331-7342. [PubMed: 6202694]

[217]. Freeman GJ, Freedman AS, Rabinowe SN, Segil JM, Horowitz J, Rosen K, Whitman JF, Nadler LM. J. Clin. Invest. 1989; 83:1512-1518. [PubMed: 2785119]

[218]. Hirano T, Ishihara K, Hibi M. Oncogene. 2000; 19:2548-2556. [PubMed: 10851053]

[219]. Harada T, Kyttaris V, Li Y, Juang YT, Wang Y, Tsokos GC. Autoimmunity. 2007; 40:1-8. [PubMed: 17364491]

[220]. Arakawa T, Masaki T, Hirai T, Doi S, Kuratsune M, Arihiro K, Kohno N, Yorioka N. Nephrol. Dial. Transplant. 2008 In press.

[221]. Tsokos GC, Boumpas DT, Smith PL, Djeu JY, Balow JE, Rook AH. Arthritis Rheum. 1986; 29:1210-1215. [PubMed: 2429672]

[222]. Kishimoto T, Hirano T. Annu. Rev. Immunol. 1988; 6:485-512. [PubMed: 3289574]

[223]. Linker-Israeli M. Clin. Immunol. Immunopathol. 1992; 63:10-12. [PubMed: 1591874]

[224]. Metsarinne KP, Nordstrom DC, Konttinen YT, Teppo AM, Fyhrquist FY. Rheumatol. Int. 1992; 12:93-96. [PubMed: 1384103]

[225]. Linker-Israeli M, Deans RJ, Wallace DJ, Prehn J, Ozeri-Chen T, Klinenberg JR. J. Immunol. 1991; 147:117-123. [PubMed: 2051017]

[226]. Spronk PE, ter Borg EJ, Limburg PC, Kallenberg CG. Clin. Exp. Immunol. 1992; 90:106-110. [PubMed: 1395090]

[227]. Kitani A, Hara M, Hirose T, Harigai M, Suzuki K, Kawakami M, Kawaguchi Y, Hidaka T, Kawagoe M, Nakamura H. Clin. Exp. Immunol. 1992; 88:75-83. [PubMed: 1563109]

[228]. Tang B, Matsuda T, Akira S, Nagata N, Ikehara S, Hirano T, Kishimoto T. Int. Immunol. 1991; 3:273-278. [PubMed: 2049341]

[229]. Murray L, Martens C. Cell Immunol. 1990; 126:367-376. [PubMed: 2138061]

[230]. Alarcon-Riquelme ME, Moller G, Fernandez C. Clin. Immunol. Immunopathol. 1992; 62:264269. [PubMed: 1541052]

[231]. Kanno K, Okada T, Abe M, Hirose S, Shirai T. Autoimmunity. 1993; 14:205-214. [PubMed: 7687154]

[232]. Levine J, Hartwell D, Beller DI. Immunol. Lett. 1991; 30:183-192. [PubMed: 1757103]

[233]. Alleva DG, Kaser SB, Beller DI. J. Immunol. 1997; 159:5610-5619. [PubMed: 9548504]

[234]. Suematsu S, Matsuda T, Aozasa K, Akira S, Nakano N, Ohno S, Miyazaki J, Yamamura K, Hirano T, Kishimoto T. Proc. Natl. Acad. Sci. USA. 1989; 86:7547-7551. [PubMed: 2798426]

[235]. Brandt SJ, Bodine DM, Dunbar CE, Nienhuis AW. J. Clin. Invest. 1990; 86:592-599. [PubMed: 2384605]

[236]. Ryffel B, Car BD, Gunn H, Roman D, Hiestand P, Mihatsch MJ. Am. J. Pathol. 1994; 144:927937. [PubMed: 8178944]

[237]. Finck BK, Chan B, Wofsy D. J. Clin. Invest. 1994; 94:585-591. [PubMed: 8040314]

[238]. Mihara M, Takagi N, Takeda Y, Ohsugi Y. Clin. Exp. Immunol. 1998; 112:397-402. [PubMed: 9649207] 


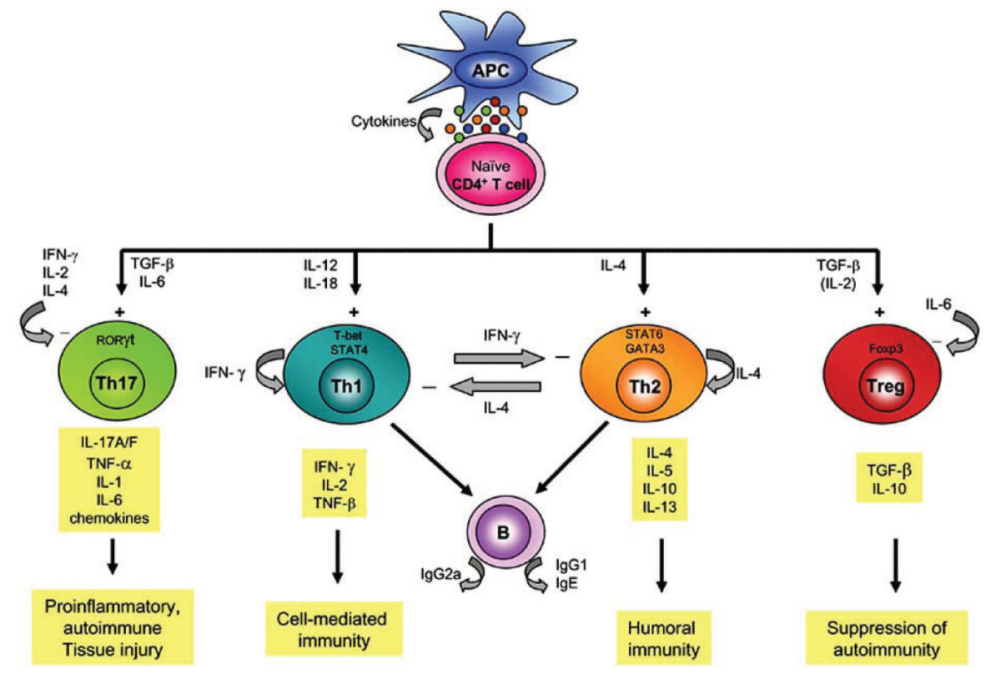

Fig. (1).

Schematic representation of the positive (+) and negative (-) effects that cytokines have on development and function of T cells. 